\title{
Qualitative and quantitative molecular analysis of bacteria in root canals of primary teeth with pulp necrosis
}

\section{Samira Salomão LEMOS(a) (iD \\ Dionéia Evangelista CESAR ${ }^{(b)}$ Stefânia Werneck PROCÓPIO(c) (iD Fernanda Campos MACHADO(d) iD Luiz Claudio RIBEIRO(e) (ID Rosangela Almeida RIBEIRO(d)}

(a) Universidade Federal de Juiz de Fora UFJF, Postgraduate Program in Dentistry, Juiz de Fora, MG, Brazil.

(b) Universidade Federal de Juiz de Fora - UFJF, Biological Sciences Institute, Department of Ecology and Molecular Biology of Microorganisms, Juiz de Fora, MG, Brazil.

(c) Universidade Federal de Minas Gerais UFMG, School of Dentistry, Postgraduate Program in Dentistry, Belo Horizonte, MG, Brazil.

(d) Universidade Federal de Juiz de Fora - UFJF, School of Dentistry, Department of Social and Child Dentistry, Juiz de Fora, MG, Brazil.

(e) Universidade Federal de Juiz de ForaUFJF, Department of Statistics, Juiz de Fora,MG, Brazil.

Declaration of Interests: The authors certify that they have no commercial or associative interest that represents a conflict of interest in connection with the manuscript.

\section{Corresponding Author:}

Rosangela Almeida Ribeiro

E-mail: ralmeida@powerline.com.br

\begin{abstract}
Information about bacterial diversity, such as the number of each species in the root canals of primary teeth, contributes to improving our effective management of infections of endodontic origin in primary teeth. This study made a qualitative and quantitative assessment of the bacteria in the root canals of primary teeth with necrotic pulp, using the fluorescence in situ hybridization (FISH) technique. Thirty-one primary teeth with pulp necrosis from 31 children were evaluated using the FISH technique, to detect the presence and density of Aggregatibacter actinomycetemcomitans, Campylobacter rectus, Enterococcus faecalis, Fusobacterium nucleatum, Porphyromonas gingivalis, Prevotella intermedia, Prevotella nigrescens, Streptococcus, Streptococcus mutans, Streptococcus sobrinus, Tannerella forsythia and Treponema denticola. Descriptive measures explained the data related to density, and Student's $t$-test assessed the differences among the densities of each bacterium, according to signs and symptoms. The bacterial density was paired and correlated. All bacteria tested were detected and identified in all the samples. The average number of bacterial individuals from each species ranged from $1.9 \times 10^{8}$ cells $/ \mathrm{mL}$ (S. mutans) to $3.1 \times 10^{8}$ cells $/ \mathrm{mL}$ (F. nucleatum) $(\mathrm{p}>0.05)$. The sum of the mean counts of each bacterium represented almost $80 \%$ of the entire microbial community. Patients with pain had significantly more $T$. denticola, and those with edema showed a greater density of Streptococcus and P. nigrescens $(\mathrm{p}<0.05)$. This study revealed that all 12 bacteria evaluated were found in all primary teeth with pulp necrosis. There was no predominance among the species studied; all species had a similar number of individuals.
\end{abstract}

Keywords: Tooth; Dental Pulp Necrosis; Bacteria; In Situ Hybridization; Fluorescence.

\section{Introduction}

Endodontic infections are caused by microorganisms in the pulp cavity. Pulpal infections in primary teeth are related to microorganism incursion and multiplication in the pulp chamber and root canals. Depending on the virulence and the number of microorganisms in the root canal, acute or chronic inflammation can be established in the periapical region. ${ }^{1,2,3,4}$ Pathological microorganisms in endodontic infections can cause abscess, 
mobility, severe pain, swelling, cysts, and even tooth loss. Moreover, they can recur after treatment. ${ }^{3}$

Endodontic treatment of primary teeth is designed to keep the teeth in healthy condition until physiological exfoliation. Treatment success is directly related to decreasing the number of microorganisms in the root canals. ${ }^{5}$ Recognizing the role played by bacteria in the pathogenesis of pulp and periapical infections makes the elimination of endodontic infection the treatment goal for teeth with necrotic pulp and periapical lesions. ${ }^{6}$ Thus, it is important to have in-depth knowledge of microbial diversity, including not only the number of species (species richness), but also the number of individuals of each species (uniformity). From an ecological perspective, a microbial community may change in regard to the number of individuals per species, in response to changing conditions that favor their growth. ${ }^{7}$ This characterization of microbial diversity in root canals of primary teeth can enable the development of more effective pulp therapies. However, knowledge of the microbiota in the endodontic infection of primary teeth is far from complete, especially in regard to component uniformity.

Few studies have assessed the microbiota of primary teeth with necrosis. . $, 6,8,9,10,11$ The techniques for culturing anaerobic bacteria have shown that endodontic infections are polymicrobial. However, the diversity of bacteria in any environment is almost always underestimated when evaluated by culturebased techniques. Molecular methods for detecting microorganisms are being used with greater frequency, because they allow the species unidentified by culture methods to be identified, and also the species to be directly determined from the clinical sample. ${ }^{12}$ Molecular methods, such as polymerase chain reaction (PCR), DNA-DNA hybridization, denaturing gradient gel electrophoresis (DGGE) and pyrosequencing, are being used to identify bacterial species that are difficult to cultivate, such as bacteria of the genera Tannerella, Treponema, Prevotella, and Porphyromonas. $3,4,8-9,10,11,13,14$ A large interindividual variability was observed in analyses by DGGE, and suggested the existence of polymicrobial communities. ${ }^{11}$

The fluorescence in situ hybridization (FISH) technique allows individual microbial cells to be visualized, identified, and quantified, and is considered a quick and objective technique for direct quantification of microorganisms. ${ }^{15,16}$ The aim of the present study was to conduct a qualitative and quantitative evaluation of the bacteria in the root canals of primary teeth with necrotic pulp, using the FISH technique.

\section{Methodology}

Thirty-one children (13 females and 18 males), ranging in age from 4 to 9 years (average age 6.29 \pm 1.27 years), were recruited from 53 children referred for pulp treatment to the Department of Pediatric Dentistry at the School of Dentistry, Universidade Federal de Juiz de Fora, Brazil. This study was approved by the human research ethics committee of the university (protocol number 226.775). Written informed consent was obtained from the parents of the children enrolled in the study.

One tooth per child was selected as a sample specimen to avert problems of correlation between observations, such as the analysis of more than one selected tooth per individual. Therefore, thirty-one root canals $(n=31)$ were selected from primary molars (five upper molars and 26 lower molars). A single canal represented the sample used to limit each bacterial evaluation to a single ecological environment. ${ }^{19}$ In multiradicular teeth, the canal with the largest caliber was chosen (the palatine canal in the upper molars, and the distal canal in the lower molars), as performed in previous studies. ${ }^{9,19}$ The sample size was also based on other Brazilian studies that used $25,{ }^{14} 30,{ }^{8} 31^{17}$ and $32^{9}$ samples.

The following inclusion criteria were applied: root canals of primary teeth diagnosed with pulp necrosis; with or without periradicular or interradicular inflammation; with intact or nonintact roots, or with resorption less than 2/3; without previous endodontic treatment; enabling absolute isolation of the operative field; and having subsequent restoration. The exclusion criteria were as follows: children having used systemic antimicrobial medication in the three months before the initial exam, using antimicrobial mouthwash, or having a systemic disease. 
A clinical chart was filled out for each participant, with identification data and anamnesis. Next, clinical and radiographic exams were performed on the tooth to be treated, in order to record the following signs and symptoms, and classify them as being present or absent: pain; edema; fistula; radiolucency in the periapical or furcation region; and pathological root resorption. These signs and symptoms were adopted in precursory studies. . $19,19,20^{2}$

\section{Specimen sampling and root canal treatment}

First, the children rinsed their mouth for 1 minute with $0.12 \%$ chlorhexidinegluconate Periogard $^{\circledR}$, Colgate-Palmolive Brasileira, Osasco, Brazil), to ensure antisepsis of the oral cavity. Then, the following procedures were performed to administer local anesthesia: absolute isolation and disinfection of the operative field was ensured using 1\% chlorhexidinegluconate (Farmácia Cavalieri ${ }^{\circledR}$, Juiz de Fora, Brazil), all decayed tissue was removed, and the operative field was again disinfected. After wards, access to the canals was made with sterile diamond burs (KG Sorensen ${ }^{\circledast}$, Cotia, Brazil), and the canals were irrigated with a small amount of sterile saline. The samples were collected with a type K \#15 file (Dentsply/Maillefer Instruments, Ballaigues, Switzerland). This file was inserted up to the working length, delimited by the initial X-ray, and set at $1 \mathrm{~mm}$ short of the radiographic apex, or the physiological root resorption limit, and smooth filing movements were made for 1 minute. ${ }^{19}$ The file was transferred to a microtube containing $2 \mathrm{~mL}$ of $2 \%$ paraformaldehyde to preserve the specimen for microbiological analysis. The root canals were cleaned and filled according to a previously described technique. ${ }^{21}$ K-files (Dentsply/ Maillefer Instruments, Ballaigues, Switzerland) were used to perform the mechanical treatment of the root canals. Initial irrigation was performed with $2.5 \%$ sodium hypochlorite ( $\mathrm{NaClO}$ 0.5\%; Farmácia Cavalieri ${ }^{\circledR}$, Juiz de Fora, Brazil) and Endo-PTC (Fórmula \& Ação Farmácia Magistral, São Paulo, Brazil). Final irrigation was made with Tergentol-Furacin, and root canal fillings were completed with Pasta Guedes-Pinto (Fórmula \& Ação Farmácia Magistral, São Paulo, Brazil), a paste composed of Rifocort ${ }^{\circledR}$, iodoform, and camphorated paramonochlorophenol. The pulp chamber was filled with ZOE cement (Pulpo-San; SS White, Rio de Janeiro, Brazil), and the tooth was sealed with self-curing glass ionomer cement (Vidrion-R; SS White, Rio de Janeiro, Brazil) until completely restored. All the steps of the specimen sampling and root canal treatment were performed by an experienced specialist researcher (SSL) in pediatric dentistry and endodontics.

\section{Microbiological analysis}

The microbiological analyses were performed by another trained researcher (SWP), who was blinded to the clinical characteristics of the cases under study. Each sample was placed in a vortex, and the contents of the microtube (file + paraformaldehyde) were transferred to a $15 \mathrm{~mL}$ Falcon tube. Then, $3 \mathrm{~mL}$ of filtered distilled water was added to the sample. The sample was sonicated three times, and filtered using a white polycarbonate filter with a pore size of $0.2 \mu \mathrm{m}$. The fluorescence in situ hybridization technique was used to identify and quantify the bacteria according to the protocol. ${ }^{22}$ Oligonucleotide probes, 16S rRNA (Operon Technologies, USA) were used, marked with Cy3 fluorochrome (indocarbocyanine) to identify bacteria of the Streptococcus genus and 11 species of bacteria (Table 1). A probe without any specificity (5'-CCTAGTGACGCCGTCGAC-3') was also used as a negative control to assess hybridization efficiency. Thus, each filter (sample) was divided into 13 parts, a piece for each probe used.

The probes were diluted with hybridization solution to a final concentration of $2.5 \mathrm{ng} \mu \mathrm{L}^{-1}$. Hybridization solutions had a specific formamide concentration for each probe (Table 1). Aliquots $(40 \mu \mathrm{L})$ of the diluted probe were placed on a slide coated with parafilm. The slides were incubated in a sealed container (hybridization chamber) at $42^{\circ} \mathrm{C}$ for at least 4 hours. After hybridization, the samples were transferred to a wash solution with a specific $\mathrm{NaCl}$ concentration (Table 1). They were then stained with DAPI (4',6-diamidino-2-phenylindole), dipped three times in $80 \%$ alcohol, and placed on absorbent paper to dry. The slide mount was created by placing the filter pieces between the slide and the coverslip, using a glycerol-PBS solution in a proportion of 7:3. The bacterial cells were counted in ten random fields 
with an Olympus BX60 epifluorescence microscope equipped with filter sets, a 31000 filter for DAPI, and a 41007 filter for $\mathrm{Cy} 3$ at 1000x magnification. The results found for the hybridized samples used a probe without specificity, and were discounted from the densities of the specific probes. The total density of microorganisms was calculated by counting the cells stained with DAPI.

\section{Statistical analysis}

All the data were processed by SPSS software (15.0, SPSS, Chicago, USA). Descriptive measures (average, standard deviation, median, minimum and maximum values) were used to explain the continuous variables related to the density (cells/mL $x 10^{8}$ ) of the tested bacteria. The Student's $t$-test was used to detect differences in the density of bacteria in patients with or without the signs and symptoms evaluated (pain, swelling, fistula, radiolucency in the periapical and/or furcation region, and pathological root resorption). The densities of all microorganisms were correlated (paired samples). The significance level for all analyses was set at $5 \%$.

\section{Results}

Among the 31 children included in the study, pain was symptomatic for $77.42 \%$ of the patients; $38.71 \%$ of the teeth presented fistula and radiolucency; $29.03 \%$, edema; and $16.13 \%$, pathological root resorption.

The descriptive measures of the density of the bacteria identified in the 31 samples of primary teeth with pulp necrosis can be seen in Table 2. The twelve bacteria tested were found in all the samples. Only average densities of F. nucleatum and S. mutans were significantly different among the samples $(p=0.006)$.

Figure 1 shows the proportion of bacteria identified with the twelve probes. Sample 7 was the sample with the lowest number of identified bacteria $\left(29.72 \times 10^{8}\right.$ cells $/ \mathrm{mL}$ from a total of $46.92 \times 10^{8}$ cells $\left./ \mathrm{mL}\right)$. On the other hand, sample 28 presented the highest number of identified bacteria $\left(45.26 \times 10^{8}\right.$ cells $/ \mathrm{mL}$ from a total of $48.11 \times 10^{8}$ cells $/ \mathrm{mL}$ ). The total bacteria-specific mean density (excluding values found for the Streptococcus genus) was $27.11 \times 10^{8}$ cells $/ \mathrm{mL}$, and corresponded to approximately $74 \%$ of the bacterial community of the root canals of primary teeth with pulp necrosis.

Densities of $T$. denticola in children with pain symptoms were significantly higher $(p=0.02)$ than those of $T$. denticola found in children without pain (Figure 2A). Primary teeth with edema also presented significantly higher densities of the P. nigrescens species $(\mathrm{p}=0.04)$ and the Streptococcus genus $(p=0.04)$, compared with teeth without edema (Figure $2 \mathrm{~B}$ ).

Table 1. Oligonucleotide probes of rRNA from microorganisms used in this study. All probes were labeled with Cy3 fluorochrome.

\begin{tabular}{|c|c|c|c|c|c|c|}
\hline Probe & Specificity & Probe sequence & $\% \mathrm{FA}^{*}$ & $\mathrm{NaCl}(\mathrm{mM})^{* *}$ & $\begin{array}{l}\text { Formamide } \\
\text { concentration }\end{array}$ & Reference \\
\hline ACAC & $\begin{array}{c}\text { Aggregatibacter } \\
\text { actinomycetemcomitans }\end{array}$ & TCCATAAGACAGATTC' & 30 & 112 & 30 & Sunde et al. $(2003)^{23}$ \\
\hline B/TAFO & Tannerella forsythia & CGTATCTCATTTTATTCCСCTGTA & 20 & 225 & 30 & Sunde et al. $(2003)^{23}$ \\
\hline CARE & Campylobacter rectus & TTAACTTATGTA AAGAAG & 35 & 80 & 20 & Riep et al. $(2009)^{24}$ \\
\hline Efs 129 & Enterococcus faecalis & СССТCTGATGGG TAGGTT & 40 & 56 & 35 & Behr et al. $(2000)^{25}$ \\
\hline FUS664 & Fusobacterium nucleatum & CTTGTAGTTCCG C(C/T)TACCTC & 30 & 112 & 40 & $\begin{array}{c}\text { Thurneer; Gmür; } \\
\text { Guggenheim }(2004)^{26}\end{array}$ \\
\hline MUT590 & Streptococcus mutans & ACTCCAGACTTT CCTGAC & 40 & 56 & 30 & Trebesius et al. $(2000)^{27}$ \\
\hline Pint649 & Prevotella intermedia & GCCGCCRCTGA ASTCAAGCC & 40 & 56 & 40 & Gmür; Thurnheer $(2002)^{16}$ \\
\hline Pnig657 & Prevotella nigrescens & TCCGCCTGCGCTGCGTGTA & 30 & 112 & 40 & Gmür; Thurnheer $(2002)^{16}$ \\
\hline POGI & Porphyromonas gingivalis & CAATACTCGTATCGCCCGTTATTC & 30 & 112 & 30 & Sunde et al. $(2003)^{23}$ \\
\hline TRE II & Treponema denticola & GCTCCTTTCCTC ATTTACCTTTAT & 40 & 56 & 30 & Moter et al. $(1998)^{28}$ \\
\hline SOB & Streptococcus sobrinus & TTAACTCCTCTT ATGCGG & 30 & 112 & 40 & Trebesius et al. $(2000)^{27}$ \\
\hline STR & Streptococcus & TAGCCGTCCCTT TCTGGT & 30 & 112 & 30 & Trebesius et al. $(2000)^{27}$ \\
\hline
\end{tabular}

*Percentage of formamide (FA) in hybridization solution; ${ }^{* *} \mathrm{NaCl}$ concentration in wash solution. 
Table 2. Descriptive measurements (average, standard deviation, median and maximum and minimum numbers) for density of bacteria $\left(\mathrm{cell} / \mathrm{mL} \times 10^{8}\right)$ in primary teeth with pulp canal and chamber necrosis.

\begin{tabular}{lccccc}
\hline \multirow{2}{*}{ Bacteria } & \multicolumn{4}{c}{ Descriptive measurements } \\
\cline { 2 - 6 } A. actinomycetemcomitans & Average & Standard deviation & Median & Minimum & Maximum \\
C. rectus & 2.46 & 2.04 & 1.82 & 0.52 & 9.76 \\
E. faecalis & 2.74 & 0.78 & 2.73 & 1.08 & 4.84 \\
F. nucleatum* & 2.05 & 0.76 & 2.21 & 0.35 & 3.24 \\
P. gingivalis & 3.12 & 2.14 & 2.65 & 0.56 & 11.27 \\
P. intermedia & 2.32 & 0.55 & 2.45 & 1.31 & 3.13 \\
P. nigrescens & 2.33 & 0.90 & 2.18 & 0.76 & 5.44 \\
Streptococcus & 2.59 & 1.55 & 2.42 & 1.15 & 9.70 \\
S. mutans* & 2.53 & 1.45 & 2.35 & 0.13 & 7.86 \\
S. sobrinus & 1.90 & 0.84 & 1.71 & 0.49 & 4.04 \\
T. forsythia & 2.38 & 0.97 & 2.20 & 0.52 & 4.36 \\
T. denticola & 2.40 & 1.07 & 2.16 & 0.62 & 6.01 \\
\hline Total microorganisms & 2.82 & 1.33 & 2.39 & 3.24 & 7.23 \\
\hline
\end{tabular}

*Significant difference $(p<0.05)$ between F. nucleatum and S. mutans.

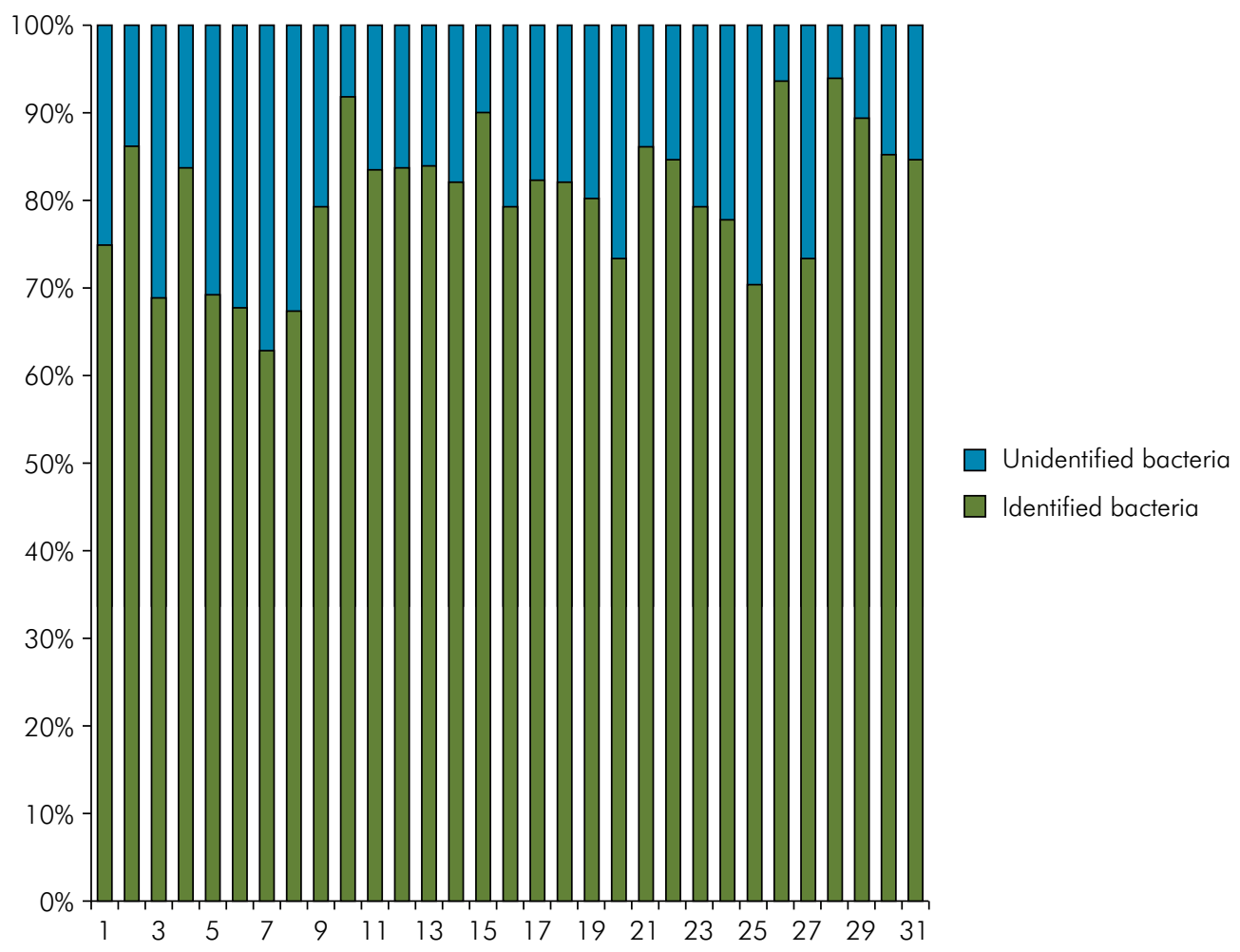

Figure 1. Average proportion of identified bacteria with the microorganisms stained with DAPI in all 31 primary teeth with pulp necrosis.

The density of $A$. actinomycetemcomitans was not significantly correlated with the density of any other bacteria studied. Table 3 shows the correlations between the densities of other bacteria. A high correlation ( $r$ between 0.8 and 0.6 ) was found between F. nucleatum and P. nigrescens $(\mathrm{p}<0.001)$, and between S. mutans and S. sobrinus $(\mathrm{p}<0.001)$. The density of F. nucleatum was moderately correlated 


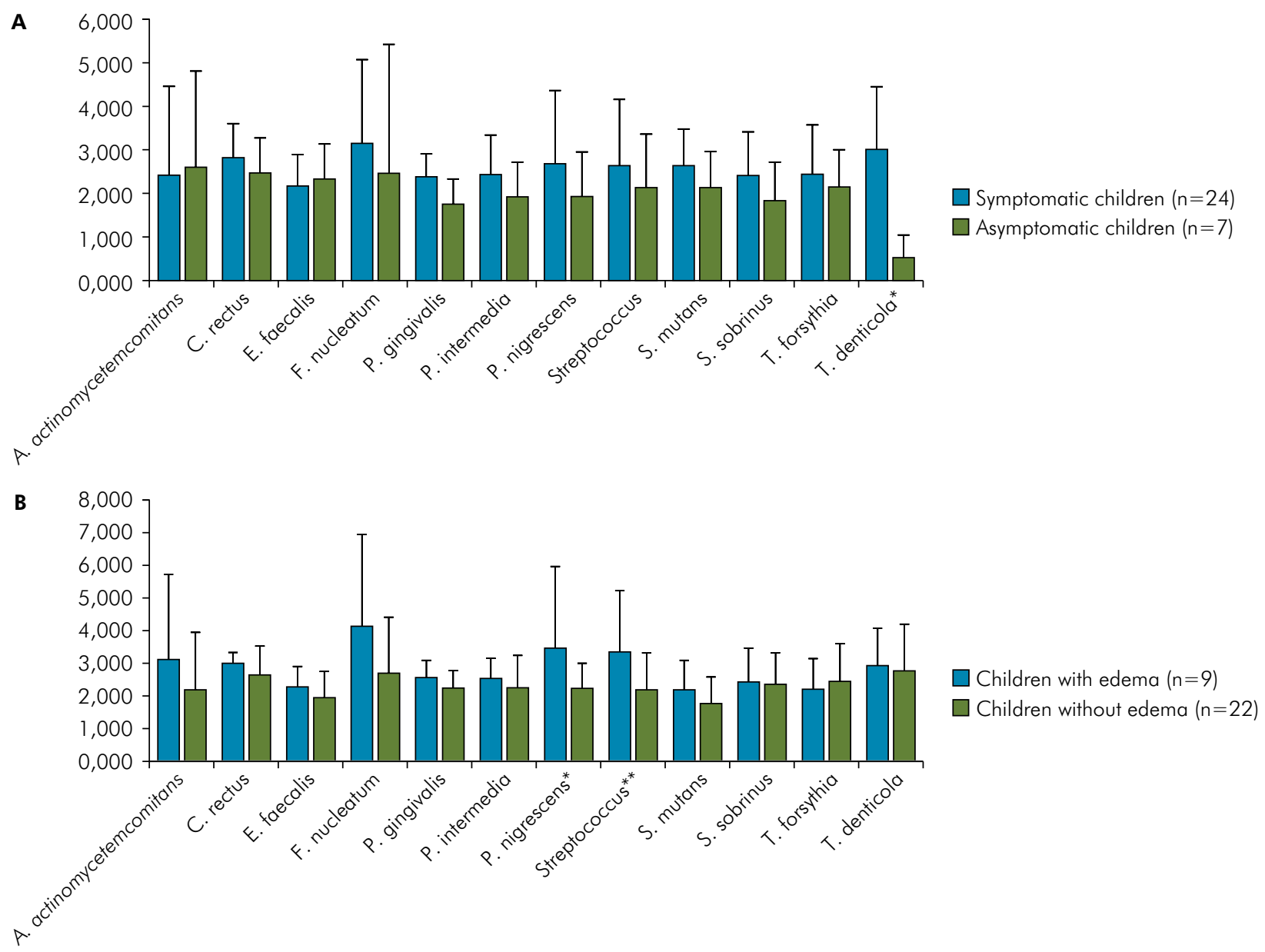

Figure 2. A.Density of bacteria (cells $10^{8} \mathrm{~mL}^{-1}$ ) in children with and without pain symptoms. Bars = standard deviation, and asterisks = significant difference. B. Density of bacteria $\left(\right.$ cells $\left.10^{8} \mathrm{~mL}^{-1}\right)$ in children with and without edema. Bars = standard deviation, and asterisks = significant difference.

( $r$ between 0.6 and 0.4 ) with the density of $P$. intermedia $(\mathrm{p}=0.022)$. The density of $S$. sobrinus was significantly correlated with the density of six other bacteria. Additionally, the density of $E$. faecalis was correlated with the densities of seven other analyzed bacteria. Streptococcus density was correlated with the two species belonging to that genus (S. mutans and S. sobrinus). Both Streptococcus species were also correlated with the density of $C$. rectus, E. faecalis, and T. forsythia. The density of $S$. sobrinus was also correlated with $P$. gingivalis and $T$. denticola. The densities of the two evaluated species of Prevotella ( $P$. intermedia and $P$. nigrescens) were moderately correlated with each other $(p=0.003)$. The moderate correlation of the density of $P$. intermedia and T. denticola was extremely significant $(\mathrm{p}<0.001)$.

\section{Discussion}

The data obtained demonstrated the polybacterial nature of endodontic infections of primary teeth with a predominance of mandatory and facultative anaerobic bacteria. The bacteria identified corresponded to approximately $80 \%$ of the total bacteria (including values found for the Streptococcus genus) and approximately $74 \%$ of the bacterial community (excluding values found for the Streptococcus genus) of the root canals of primary teeth with pulp necrosis. This result underscores that this species of bacteria was appropriately chosen for our test purposes, despite the diversity of species that can exist in cases of infections in root canals with necrotic pulp. It is also worth noting that the bacteria that were identified are 
Table 3. Correlation ( $r$ ) between the densities of the bacteria tested in this study.

\begin{tabular}{|c|c|c|c|c|c|c|c|c|c|c|}
\hline Bacteria & C. rectus & E. faecalis & F. nucleatum & P. gingivalis & P. intermedia & P. nigrescens & Streptococcus & S. mutans & S. sobrinus & T. forsythia \\
\hline E. faecalis & $0.394^{*}$ & & & & & & & & & \\
\hline F. nucleatum & - & - & & & & & & & & \\
\hline P. gingivalis & - & $0.390^{*}$ & - & & & & & & & \\
\hline P. intermedia & - & $0.557^{* *}$ & $0.411^{* *}$ & - & & & & & & \\
\hline P. nigrescens & - & $0.387^{*}$ & $0.724^{* * *}$ & - & $0.509^{* *}$ & & & & & \\
\hline Streptococcus & $0.380^{*}$ & - & - & $0.413^{*}$ & - & - & & & & \\
\hline S. mutans & $0.525^{* *}$ & $0.577^{* *}$ & - & - & - & - & $0.403^{* *}$ & & & \\
\hline S. sobrinus & $0.490^{* *}$ & $0.401^{* *}$ & - & $0.535^{* *}$ & - & - & $0.391^{*}$ & $0.697^{* * *}$ & & \\
\hline T. forsythia & - & - & - & $0.372^{*}$ & $0.535^{* *}$ & - & - & $0.426^{*}$ & $0.562^{* *}$ & \\
\hline T. denticola & - & $0.371^{*}$ & - & - & $0.567^{* * *}$ & - & - & - & $0.469^{* *}$ & $0.432^{* *}$ \\
\hline
\end{tabular}

Asterisks represent significance levels: ${ }^{*}$ low correlation ( $r$ between 0.4 and 0.1$) ;{ }^{* *}$ moderate correlation $(r$ between 0.6 and 0.4$) ;{ }^{* * *}$ high correlation ( $r$ between 0.8 and 0.6 ).

included among the bacterial genera most frequently detected in primary endodontic infections. ${ }^{29}$

Knowledge of this polymicrobial nature of bacteria is of utmost importance, because their behavior can change, and become more virulent due to stresses arising from adverse environmental conditions, such as an increase in population density, lack of nutrients, and changes in $\mathrm{pH}$ and temperature. Under these conditions, the microorganisms develop an adaptation or defense mechanism, whereby they communicate intracellularly through molecular signaling, aligned with concepts of the biofilm and microbial community. Thus, the intra- or interspecies relations increase the chance of the microorganisms to survive in the environment, and the infection to become more resistant. ${ }^{30}$

The heterogeneity of the oral microbiota was greater than previously believed. The microbiota of the root canals of primary teeth were previously investigated by culture and molecular methods. $910,17,18,19,31$ The cultivation technique can be fastidious. Additionally, some microorganisms are uncultured and cannot be identified by this methodology. Endodontic microbiota has been clearly redefined by molecular methods. Thus, variations in prevalence data are changing, and the species richness and uniformity values are increasing. However, in some cases, the number of bacteria present in the environment is below the level of detection by the technique chosen, there by masking its prevalence. Furthermore, dead and inactive bacteria are included in the quantification using molecular techniques. ${ }^{9}$
FISH has a $10^{3}$ cell detection limit, ${ }^{32}$ but may concentrate larger sample volumes to increase the number of cells. This technique is a rapid and objective method that provides direct quantitative results, without a prior culture or amplification of nucleic acids. The bacterial individuals can be visualized and quantified by microscopy or flow cytometry. Viewing through a microscope also allows analysis of morphological characteristic of microbial cells and spatial distribution patterns (aggregates, adhered and isolated cells). ${ }^{15,33}$ Microscopic study shows that dense aggregate-forming bacteria in the root canal wall are formed by various different morphological types, suggesting their co-aggregation..$^{29}$

However, errors may occur, mainly in cases whose target microorganisms are autofluorescent. FISH requires a targeted investigation, because the specificity of the probes used can lead to false positive results. The use of positive and negative control samples, and the choice of probes labeled with Cy3 offset possible limitations. ${ }^{15,34}$ As previously described in the methods section, we used a negative control here in, and chose to use probes labeled with Cy3 specifically to offset limitations of the FISH technique.

Fusobacterium nucleatum was, on average, the most abundant bacterium in the root canal system of the examined teeth, and was significantly different only from S. mutans regarding average density. F. nucleatum is considered an intermediate colonizing species, and can be found in both symptomatic and 
asymptomatic infections. It may facilitate invasion by other bacteria, triggered by physical and chemical changes. High prevalence and ability to co-aggregate with other species may be related to its low proteolytic capability ${ }^{33,35}$ Although also present in all the samples, S. sobrinus had the lowest average bacterial density. The difference in prevalence can be explained by possible exposure of only a few canals to the oral cavity, an outcome which would increase the presence of $S$. mutans. ${ }^{17}$ In this study, none of the teeth selected and treated had root canals that communicated with the oral environment.

An important result of this study was the observation of the E. faecalis species in all samples. Few studies conducted with molecular methods have previously observed E. faecalis in deciduous teeth, ${ }^{9,14,19,31}$ but none of them with the frequency which we observed. E. faecalis is an opportunistic pathogen that can withstand chemical and mechanical treatment, and also high $\mathrm{pH}$ levels, owing to its biofilm formation potential, and to the operation of a proton pump that reduces intracytoplasmic $\mathrm{pH}^{14,36,37}$ Although E. faecalis is the most common pathogen associated with secondary infection in permanent teeth, ${ }^{14,38,39}$ the authors did not associate this species with the failure of endodontic treatment of primary teeth. Even so, E. faecalis can acquire resistance to the antimicrobials commonly used in endodontic treatments. It should be highlighted that the ability to detect how and why this bacterium favors or rejects different endodontic infections is a matter of particular interest. ${ }^{36,37,39}$

Infections of the root canal space with Gram-negative, facultative, and obligate anaerobic bacteria have been associated with different clinical signs and symptoms. Sensitive and accurate molecular techniques are needed to characterize the root canal bacterial irritants, in order to determine their association with clinical symptoms and treatment prognosis. ${ }^{19}$ There was no correlation between the number of bacteria and the presence of fistula, injury or pathological root resorption in our samples.

Teeth with edema had more bacteria of Streptococcus genus and $P$. nigrescens species than teeth without edema. These bacteria are frequently associated with acute apical abscesses, as well as other Gram-negative bacilli, including Fusobacterium, Porphyromonas, Dialister and Treponema. ${ }^{40}$

A meta-analysis showed the heterogeneity in the prevalence rates of the Treponema species in primary and secondary infections, whether symptomatic or not. ${ }^{41}$ The authors of a previous study emphasized the importance of these species, particularly in cases of acute primary infection. The participation of T. denticola in the pathogenesis of acute apical abscess was evaluated using real-time PCR. ${ }^{13}$ The authors of that study found an association between the bacteria of the species and symptomatic infections. ${ }^{18,19}$ They proved in their study that $T$. denticola and E. faecalis bacteria were highly associated with periapical radiolucency and previous pain, whereas $P$. gingivalis was associated with tenderness to percussion in both primary and permanent teeth. In our study, bacteria of the T. denticola species were found in all children's teeth evaluated (100\% prevalence). Using the FISH technique, we were able to quantify children with pain symptoms as having more $T$. denticola. In a bacterial community, $T$. denticola does not commonly become more virulent, or increase the virulence of other community species. ${ }^{18}$

Bacterial correlations such as Porphyromonas spp./ Prevotella spp. and P. gingivalis/Enterococcus spp. were detected, suggesting that these bacteria are able to survive in necrotic tissues, whether alone or in association. The availability of nutrients, low oxygen tension and bacterial interactions are important ecological determinants for these bacteria in root canals with necrotic pulp. ${ }^{6} P$. gingivalis has been described as a species with proteolytic enzymes and more pathogenic microorganisms, identified from its black pigment. The association of different bacterial species in infected root canals of primary teeth seems to activate the immune response of the host. However, these same bacteria may compete for the same receptor, or may activate different receptors interfering with the transcription of inflammatory proteins. ${ }^{1}$

Again, the quantification of specific bacteria can contribute to the understanding of this process, since a larger number of bacterial individuals of a given species may proportionally make these individuals better competitors. Likewise, the 
concentration of endotoxin is related not only to the microorganisms that produce the bacteria, but also to the metabolic activity of the bacteria and the number of individuals. Whereas all are active, the greater the number of individuals, the greater the production. The degree of severity of an endodontic infection is not related to the mere presence of pathogens, but to the number of these microorganisms at the infected site..$^{42}$

\section{Conclusion}

In conclusion, this study showed that all 12 bacteria evaluated were found in all primary teeth with pulp necrosis. There was no predominance among the species studied; all species had a similar number of bacterial individuals. Not only the prevalence, but also the component uniformity of the diversity confirmed the nature of the polymicrobial infection.

Our results provide information on bacterial diversity, such the number of species, and the number of individuals of each species of bacteria present in the root canals of primary teeth, detected using the FISH technique. This method has proven effective in detecting, identifying and enumerating the microbiota of primary teeth with pulpal necrosis. This information improves our effective management of infections of endodontic origin in primary teeth.

\section{Acknowledgments}

The authors would like to thank Capes for their financial support.

\section{References}

1. Martinho FC, Leite FR, Nascimento GG, Cirelli JA, Gomes BP. Clinical investigation of bacterial species and endotoxin in endodontic infection and evaluation of root canal content activity against macrophages by cytokine production. Clin Oral Investig. 2014 Dec;18(9):2095-102. https://doi.org/10.1007/s00784-014-1198-1

2. Zehnder M, Belibasakis GN. On the dynamics of root canal infections-what we understand and what we don't. Virulence. 2015;6(3):216-22. https://doi.org/10.4161/21505594.2014.984567

3. Yun KH, Lee HS, Nam OH, Moon CY, Lee JH, Choi SC. Analysis of bacterial community profiles of endodontically infected primary teeth using pyrosequencing. Int J Paediatr Dent. 2017 Jan;27(1):56-65. https://doi.org/10.1111/ipd.12226

4. Nelson-Filho P, Ruviére DB, Queiroz AM, Paula-Silva FW, Silva RA, Lucisano MP, et al. Comparative molecular analysis of gram-negative bacteria in primary teeth with irreversible pulpitis or periapical pathology. Pediatr Dent. 2018 Jul;40(4):259-64.

5. Blome B, Braun A, Sobarzo V, Jepsen S. Molecular identification and quantification of bacteria from endodontic infections using real-time polymerase chain reaction. Oral Microbiol Immunol. 2008 Oct;23(5):384-90. https://doi.org/10.1111/j.1399-302X.2008.00440.x

6. Fabris AS, Nakano V, Avila-Campos MJ. Bacteriological analysis of necrotic pulp and fistulae in primary teeth. J Appl Oral Sci. 2014 Apr;22(2):118-24. https://doi.org/10.1590/1678-775720130358

7. Sogin ML, Morrison HG, Huber JA, Mark Welch D, Huse SM, Neal PR, et al. Microbial diversity in the deep sea and the underexplored "rare biosphere". Proc Natl Acad Sci USA. 2006 Aug;103(32):12115-20. https://doi.org/10.1073/pnas.0605127103

8. Ito IY, Matoba Junior F, Paula-Silva FW, Silva LA, Leonardo MR, Nelson-Filho P. Microbial culture and checkerboard DNA-DNA hybridization assessment of bacteria in root canals of primary teeth pre- and post-endodontic therapy with a calcium hydroxide/chlorhexidine paste. Int J Paediatr Dent. 2011 Sep;21(5):353-60. https://doi.org/10.1111/i.1365-263X.2011.01131.x

9. Tavares WL, Brito LCN, Teles RP, Massara ML, Ribeiro Sobrinho AP, Haffajee AD, et al. Microbiota of deciduous endodontic infections analysed by MDA and Checkerboard DNA-DNA hybridization. Int Endod J. 2011 Mar;44(3):225-35. https://doi.org/10.1111/i.1365-2591.2010.01805.x

10. Topcuoglu N, Bozdoğan E, Kulekci G, Aktoren O. Presence of oral bacterial species in primary endodontic infections of primary teeth. J Clin Pediatr Dent. 2013;38(2):155-60. https://doi.org/10.17796/icpd.38.2.5252712533082gt0

11. Paula VA, Ferreira DC, Cavalcante FS, Carmo FL, Rosado AS, Primo LG, et al. Clinical signs and bacterial communities of deciduous necrotic root canals detected by PCR-DGGE analysis: research association. Arch Oral Biol. 2014 Aug;59(8):848-54. https://doi.org/10.1016/i.archoralbio.2014.05.012

12. Arathi K, Prasad G, Shetty SJ, lype AK. Uncultivable bacteria in the oral cavity: a review. Int J Adv Health Sci. 2015 Mar;1(11):16-9.

13. Ozbek SM, Ozbek A, Erdogan AS. Detection of treponema denticola in symptomatic apical periodontitis and in symptomatic apical abscesses by real-time PCR. Eur J Dent. 2009 Apr;3(2):107-13. https://doi.org/10.1055/s-0039-1697416 
Qualitative and quantitative molecular analysis of bacteria in root canals of primary teeth with pulp necrosis

14. Cancio V, Ferreira DC, Cavalcante FS, Rosado AS, Teixeira LM, Oliveira QB, et al. Can the Enterococcus faecalis identified in the root canals of primary teeth be a cause of failure of endodontic treatment? Acta Odontol Scand. 2017 Aug;75(6):423-8. https://doi.org/10.1080/00016357.2017.1328742

15. Moter A, Göbel UB. Fluorescence in situ hybridization (FISH) for direct visualization of microorganisms. J Microbiol Methods. 2000 Jul;41(2):85-112. https://doi.org/10.1016/S0167-7012(00)00152-4

16. Gmür R, Thurnheer T. Direct quantitative differentiation between Prevotella intermedia and Prevotella nigrescens in clinical specimens. Microbiology. 2002 May;148(P+ 5):1379-87. https://doi.org/10.1099/00221287-148-5-1379

17. Pazelli LC, Freitas AC, Ito IY, Souza-Gugelmin MC, Medeiros AS, Nelson-Filho P. Prevalence of microorganisms in root canals of human deciduous teeth with necrotic pulp and chronic periapical lesions. Pesqui Odontol Bras. 2003 Oct-Dec;17(4):367-71. https://doi.org/10.1590/S1517-74912003000400013

18. Gomes BP, Pinheiro ET, Gadê-Neto CR, Sousa EL, Ferraz CC, Zaia AA, et al. Microbiological examination of infected dental root canals. Oral Microbiol Immunol. 2004 Apr;19(2):71-6. https://doi.org/10.1046/i.0902-0055.2003.00116.x

19. Cogulu D, Uzel A, Oncag O, Eronat C. PCR-based identification of selected pathogens associated with endodontic infections in deciduous and permanent teeth. Oral Surg Oral Med Oral Pathol Oral Radiol Endod. 2008 Sep;106(3):443-9. https://doi.org/10.1016/i.tripleo.2008.03.004

20. Gomes GB, Sarkis-Onofre R, Bonow ML, Etges A, Jacinto RC. An investigation of the presence of specific anaerobic species in necrotic primary teeth. Braz Oral Res. 2013 Mar-Apr;27(2):149-55. https://doi.org/10.1590/S1806-83242013000100020

21. Guedes-Pinto AC, Paiva JG, Bozzola JR. Tratamento endodôntico de dentes decíduos com polpa mortificada. Rev Assoc Paul Cir Dent. 1981 May-Jun;35(3):240-4.

22. Machado FC, Cesar DE, Assis AV, Diniz CG, Ribeiro RA. Detection and enumeration of periodontopathogenic bacteria in subgingival biofilm of pregnant women. Braz Oral Res. 2012 Sep-Oct;26(5):443-9. https://doi.org/10.1590/S1806-83242012000500011

23. Sunde PT, Olsen I, Gobel UB, Theegarten D, Winter S, Debelian GJ, et al. Fluorescence in situ hybridization (FISH) for direct visualization of bacteria in periapical lesions of asymptomatic root-filled teeth. Microbiology. 2003 May; 149(P+ 5):1095-102. https://doi.org/10.1099/mic.0.26077-0.

24. Riep B, Edesi-Neuss L, Claessen F, Skarabis H, Ehmke B, Flemmig TF, et al. Are putative periodontal pathogens reliable diagnostic markers? J Clin Microbiol. 2009 Jun;47(6):1705-11. Htttps://doi.org/10.1128/JCM.01387-08

25. Behr T, Koob C, Schedl M, Mehlen A, Knopp D, Frahm E, et al. A nested array of rRNA targeted probes for the detection and identification of Enterococci by reverse hybridization. Syst Appl Microbiol. 2000 Dec;23(4):563-72. https://doi.org/10.1016/s0723-2020(00)80031-4

26. Thurnheer T, Gmür R, Guggenheim B. Multiplex FISH analysis of a six species bacterial biofilm. J Microbiol Methods. 2004 Jan;56(1):37-47. https://doi.org/10.1016/i.mimet.2003.09.003

27. Trebesius K, Leitritz L, Adler K, Schubert S, Autenrieth IB, Heesemann J. Culture independent and rapid identification of bacterial pathogens in necrotising fasciitis and Streptococcal toxic shock syndrome by fluorescence in situ hybridisation. Med Microbiol Immunol. 2000 Jun;188(4):169-75. https://doi.org/ 10.1007/s004300000035

28. Moter A, Hoenig C, Choi BK, Riep B, Gobel UB. Molecular epidemiology of oral treponemes associated with periodontal disease. J Clin Microbiol. 1998 May;36(5):1399-403. https://doi.org/10.1128/JCM.36.5.1399-1403.1998

29. Siqueira Junior JF, Rôças IN, Lopes HP. Patterns of microbial colonization in primary root canal infections. Oral Surg Oral Med Oral Pathol Oral Radiol Endod. 2002 Feb;93(2):174-8. https://doi.org/10.1067/moe.2002.119910

30. Ferreira NS, Martinho FC, Cardoso FG, Nascimento GG, Carvalho CA, Valera MC. Microbiological profile resistant to different intracanal medications in primary endodontic infections. J Endod. 2015 Jun;41(6):824-30. https://doi.org/10.1016/i.joen.2015.01.031

31. Triches TC, Figueiredo LC, Feres M, Freitas SF, Zimmermann GS, Cordeiro MM. Microbial profile of root canals of primary teeth with pulp necrosis and periradicular lesion. J Dent Child (Chic). 2014 Jan-Apr;81(1):14-9.

32. Li M, Gu JD. Advances in methods for detection of anaerobic ammonium oxidizing (anammox) bacteria. Appl Microbiol Biotechnol. 2011 May;90(4):1241-52. https://doi.org/10.1007/s00253-011-3230-6

33. Schillinger C, Petrich A, Lux R, Riep B, Kikhney J, Friedmann A, et al. Co-localized or randomly distributed? Pair cross correlation of in vivo grown subgingival biofilm bacteria quantified by digital image analysis. PLoS One. 2012;7(5):e37583. https://doi.org/10.1371/journal.pone.0037583

34. Frickmann H, Zautner AE, Moter A, Kikhney J, Hagen RM, Stender H, et al. Fluorescence in situ hybridization (FISH) in the microbiological diagnostic routine laboratory: a review. Crit Rev Microbiol. 2017 May;43(3):263-93. https://doi.org/10.3109/1040841X.2016.1169990

35. Sassone LM, Fidel RA, Faveri M, Guerra R, Figueiredo L, Fidel SR, et al. A microbiological profile of symptomatic teeth with primary endodontic infections. J Endod. 2008 May;34(5):541-5. https://doi.org/10.1016/i.joen.2008.02.004

36. Foschi F, Cavrini F, Montebugnoli L, Stashenko P, Sambri V, Prati C. Detection of bacteria in endodontic samples by polymerase chain reaction assays and association with defined clinical signs in Italian patients. Oral Microbiol Immunol. 2005 Oct;20(5):289-95. https://doi.org/10.1111/j.1399-302X.2005.00227.x 
37. Stojanović N, Krunić J, Popović B, Stojičić S, Zivković S. Prevalence of Enterococcus faecalis and Porphyromonas gingivalis in infected root canals and their susceptibility to endodontic treatment procedures: a molecular study. Srp Arh Celok Lek. 2014 SepOct;142(9-10):535-41. https://doi.org/10.2298/SARH1410535S

38. Endo MS, Ferraz CC, Zaia AA, Almeida JF, Gomes BP. Quantitative and qualitative analysis of microorganisms in root-filled teeth with persistent infection: monitoring of the endodontic retreatment. Eur J Dent. 2013 Jul; 7(3):302-9. https://doi.org/10.4103/1305-7456.115414

39. Colaco AS. Extreme resistance of Enterococcus faecalis and its role in endodontic treatment failure. Prog Med Sci. 2018;2(1):9-13. https://doi.org/10.5455/pms.20180116070109

40. Gomes BP, Herrera DR. Etiologic role of root canal infection in apical periodontitis and its relationship with clinical symptomatology. Braz Oral Res. 2018 Oct;32 suppl 1:e69. https://doi.org/10.1590/1807-3107bor-2018.vol32.0069

41. Leite FR, Nascimento GG, Demarco FF, Gomes BP, Pucci CR, Martinho FC. Prevalence of treponema species detected in endodontic infections: systematic review and meta-regression analysis. J Endod. 2015 May;41(5):579-87. https://doi.org/10.1016/i.joen.2015.01.020

42. Jung IY, Choi B, Kum KY, Yoo YJ, Yoon TC, Lee SJ, et al. Identification of oral spirochetes at the species level and their association with other bacteria in endodontic infections. Oral Surg Oral Med Oral Pathol Oral Radiol Endod. 2001 Sep;92(3):329-34. https://doi.org/10.1067/moe.2001.117263 